\title{
Testing the capital structure of Portuguese family businesses ${ }^{\star}$
}

\author{
Luciana J. Pestana ${ }^{1}$ \\ (D) https://orcid.org/0000-0002-5388-6779 \\ Email: lucianapestana_25@hotmail.com \\ Luís Pereira Gomes ${ }^{2,3}$ \\ (D) https://orcid.org/0000-0001-9792-1049 \\ Email: pgomes@iscap.ipp.pt \\ Cristina Lopes ${ }^{2,3}$ \\ (D) https://orcid.org/0000-0002-4833-470X \\ Email: cristinalopes@iscap.ipp.pt
}

\footnotetext{
${ }^{1}$ Acertotal - Consultoria de Condomínios, Lda, Departamento Financeiro, Funchal, Portugal

${ }^{2}$ Instituto Politécnico do Porto, Instituto Superior de Contabilidade e Administração do Porto, São Mamede de Infesta, Portugal

${ }^{3}$ Instituto Politécnico do Porto, Centro de Estudos Organizacionais e Sociais, São Mamede de Infesta, Portugal
}

Received on 10.21.2020 - Desk acceptance on 11.30.2020 - 2nd version approved on 03.16.2021

Editor-in-Chief: Fábio Frezatti

Associate Editor: Fernanda Finotti Cordeiro

\section{ABSTRACT}

The main objective of this study is to empirically test capital structure decisions in Portuguese family-owned businesses under trade-off theory (TOT) and pecking order theory (POT) and attend to the relationships between family/business interaction and agency conflicts. Family-owned businesses are essential for the development of economies, but the financing logic they adopt is not yet adequately clarified by scientific research, especially as they are more exposed to the constraints of markets imperfections. The specific pattern of business ownership may affect the financing decision and the ability to obtain funds externally. This issue is more relevant in economies where family business initiatives and less sophisticated management strategies are expressive. The greater convergence of interests in family businesses and the consequent decrease in agency costs may lead to higher levels of recognized reputation and thus easier access to indebtedness. The empirical study uses static models and dynamic panel models in order to analyze data from 4,952 Portuguese family-owned firms over the period from 2009 to 2016: the TOT following the partial debt adjustment model, and the POT following the model of the impact of the deficit of funds on debt and the model of the relationship between debt and the determinants of financing. The results of the individual tests suggest that Portuguese family-owned businesses adjust debt at the target ratio, albeit influenced by adjustment costs that keep them distant from the optimal, as well as use sources other than debt when a financial deficit occurs. Although the impact of the financial deficit is greater in total debt ratio, the velocity of adjustment to the optimal level is higher in short-term debt. Evidence from a joint test confirms that both theories explain part of the capital structure of Portuguese family-owned businesses.

Keywords: family businesses, capital structure, trade-off theory, pecking order theory, panel data.

Correspondence address

Luís Pereira Gomes

Instituto Politécnico do Porto, Instituto Superior de Contabilidade e Administração do Porto

Rua Jaime Lopes Amorim, s/n - 4465-004

São Mamede de Infesta - Portugal

* Work presented at the XVIII Encontro AECA (Asociación Española de Contabilidad y Administración de Empresas), September of 2018, Lisboa, Portugal. 


\section{INTRODUCTION}

The way companies finance themselves, the factors that determine such decisions, and how these choices affect the economy are key issues that have been discussed over time (Frank \& Goyal, 2008). Several business theories have emerged to explain the factors that influence decisions about the capital structure of firms, notably the trade-off theory (TOT) by Kraus and Litzenberger (1973) and the pecking order theory (POT) by Myers and Majluf (1984).

The financing decisions of family businesses have been relatively ignored (Keasey et al., 2015). However, Gottardo and Moisello (2014) declare that, although the funding patterns adopted by these companies are not yet adequately clarified, research on the subject has been gathering interest.

Family-run businesses are usually affected by the duality of objectives, which are reflected in the renouncement of share issuance and in the junction of family and business finances (Csákné \& Karmazin, 2016). In this context, non-economic factors are highly relevant, and may justify differences in the use of financing sources and in the decision-making process (Acedo-Ramírez et al., 2017; Mohamadi, 2012). Gallo et al. (2004) argue that family businesses have their own "financial logic" where the specific pattern of ownership can affect policies and funding, as well as the ability to obtain external resources. Considering that family businesses, with traits of stability and growth expectations, are essential for the development of the economy, it becomes relevant to clarify the financing patterns they adopt. This is the motivation of choosing the theme.

Managers believe in the worst-case about the expected risk-adjusted earnings before interest and taxes (EBIT) behavior, implying a distortion of restructuring likelihood. This essential feature justifies that companies display a weaker willingness to readjust leverage by choosing a slower pace and smaller size of adjustment (Ban \& Chen,
2019). On the other hand, Liu et al. (2020) showed that executive compensation motivates chief executive officer (CEOs) to pursue more aggressive capital structure policy. Even so, the larger leverage is due to better access to debt, which results in lower rebalancing costs (Chernenko, 2019).

The main objective of this article is to understand if Portuguese family businesses seek to achieve an optimized capital structure, as provided by TOT, or if they prefer to deplete internal funds before resorting to external sources of financing, as foreseen by POT.

The empirical study uses panel data methodology. The TOT test follows the partial adjustment model using the generalized method of moments (GMM) system estimator by Blundell and Bond (1998). The POT test follows two models: (i) the model suggested by ShyamSunder and Myers (1999), regarding the impact of the deficit of funds on the debt variation, using an ordinary least squares (OLS) regression; and (ii) the model for the relationship between debt and the financing determinants, using static panel models, an OLS regression, a fixed effects model, and a random effects model. In turn, the fixed effects model and the random effects model are calculated using the White (1980) estimator. Finally, the verification of the robustness of the results resorts to a joint test to the two theories, again using the GMM system estimator.

The structure of the article is organized as follows. Section 2 describes international empirical evidence on the subject. Section 3 is devoted to the methodology discussed in the empirical study, defining the tests of the capital structure theories and raising the hypothesis of investigation. Subsequently, the sample is selected, the proxies of the models are defined, and the descriptive statistics are determined. Section 5 presents and discusses the test results. Finally, the main conclusions are summarized.

\section{EMPIRICAL EVIDENCE}

Family-owned enterprises have a strong presence in the world's economies, contributing to the transmission of knowledge, boosting competitiveness, and generating wealth, especially in the less industrialized regions. Despite the importance of family businesses, the relationship between ownership and financing decisions is still little explored in the literature (Bauweraerts \& Colot, 2012; López-Gracia \& Sánchez-Andújar, 2007; Serrasqueiro et al., 2012, 2016). The peculiar characteristics of these companies, such as family presence, risk aversion, and the desire for business continuity in family ownership, influence financial behavior (Correia, 2003; Gottardo 
\& Moisello, 2014; Vieira, 2014). In addition, this desire conditions the entry of third parties into corporate capital (Blanco-Mazagatos et al., 2009; Romano et al., 2001).

On the other hand, family-owned enterprises are mostly small and medium-sized enterprises (SMEs), for which there are constraints on access to external capital (Bjuggren et al., 2012; Martinez et al., 2021). For example, the market imperfections lead to financial constraints on investment and can magnify the macroeconomic effect of shocks to liquidity that reduce some firms' access to low-cost finance and worsen their balance sheet positions (Fazzari et al., 1988). The determinant size as a measure of financial constraints is justified because small companies are typically young, less known, and therefore more vulnerable to capital market imperfections (Almeida \& Campello, 2010). Therefore, financial institutions that specialize in long-term borrower relationships and in balance sheet assessment can be useful in financing smaller firms without access to commercial paper, bonds, and equity market (Fazzari et al., 1988).

Oftentimes, family enterprises face problems related to capital structure as they are characterized by privately held entities. Generally, liquidity imbalances are solved by family members through the reallocation of resources (Csákné \& Karmazin, 2016; European Commission [EC], 2009). With regard to successfully established companies, the main financial resources consist of retained earnings, short-term bank loans, and family savings (Csákné \& Karmazin, 2016).

Founding families see the company as an asset that will be passed on over the course of future generations (Chami, 2001; Hillen \& Lavarda, 2020). While some owners/administrators are more cautious about debt in order to minimize the interference of external agents (Ampenberger et al., 2013; Blanco-Mazagatos et al., 2007; Mishra \& McConaughy, 1999), others prefer debt, in order to keep the control of the company in the family (Gottardo \& Moisello, 2014; Keasey et al., 2015; King \& Santor, 2008).

In the context of the agency theory, presented by Jensen and Meckling (1976), family businesses are considered more efficient because the principal and the agent are generally the same person or have homogeneous interests. The literature shows that agency costs are lower because of the greater alignment of interests among family members (Schulze et al., 2003a, 2003b; Steier et al., 2004; Woodman, 2017) and due to their risk aversion, the preservation of social ties, and the holding of less onerous debts (Mohamadi, 2012), since creditors identify the image and reputation of both the family and the company. This seems to justify the fact that family businesses have low agency costs that motivate a negative relationship between family ownership and indebtedness. However, emerging problems of the ingrained ownership, information asymmetry, and altruism may determine the use of debt as a form of monitoring.

As for the predominance of the TOT or the POT in financing decisions, the scientific evidence is mixed, suggesting that family businesses may choose to establish a target debt level or to determine a hierarchy of funding sources.

A number of studies have identified that family businesses first exhaust internal resources to meet funding needs (Ampenberger et al., 2013; Mehboob et al., 2015; Mohamadi, 2012) and only later use external funding as predicted by the POT. In this context, equity financing is deferred to debt financing (Croci et al., 2011) in order to avoid opening the capital to third parties due to fear of losing business control (Gottardo \& Moisello, 2014). Thus, the relationship between internal funds and external financing can be substantially affected by the endogeneity of investment when firms are financially constrained (Almeida \& Campello, 2010).

Other studies have identified that family businesses set goals by adjusting the actual indebtedness to the optimal level, counterbalancing the costs and the benefits resulting from indebtedness (Acedo-Ramírez et al., 2017; Tahir et al., 2016), as provided by the TOT.

Complementarily, Serrasqueiro et al. (2016) concluded that the financing decisions of younger and smaller companies are more in line with the POT's assumptions, while older and larger companies align with the TOT.

\section{METHODOLOGY}

\subsection{Testing the TOT}

From the perspective of the TOT, companies continually revert their actual indebtedness to optimum "target" debt. In this context, we followed the procedure described by Fama and French (2002), Sogorb-Mira and López-Gracia (2003), and Shyam-Sunder and Myers
(1999). Here we analyze the variation of the debt ratio towards the optimal, using the partial adjustment model, and verify the speed of this adjustment. The partial adjustment model is expressed by equation 1 :

$$
D_{i t}-D_{i t-1}=\lambda\left(D_{i t}^{*}-D_{i t-1}\right)
$$


Solving for $D_{i t}$, the current level of indebtedness is defined by equation 2 :

$$
D_{i t}=\lambda D_{i t}^{*}+(1-\lambda) D_{i t-1}
$$

where $D_{i t}$ is the level of debt of the firm $i$ in the period of time $t, D_{i t-1}$ is its level of debt in the previous period, $D^{*}$ is the optimal level of debt of the firm $i$ in period $t, \lambda$ is the speed of adjustment of the actual level of the debt to the optimal, and (1- $\lambda)$ are the adjustment costs.

To compare the results, we consider three dependent variables indicative of corporate debt (Table 1).

Table 1

Description of dependent variables

\begin{tabular}{lccc}
\hline Dependent variable & Notation & Proxy & Authors \\
\hline Total debt ratio & $D_{i t}$ & $\frac{\text { Total Liabilities }}{\text { Total Asset }}$ & $\begin{array}{c}\text { Acedo-Ramírez et al. (2017), Adair and Adaskou (2015), Caetano (2011), } \\
\text { Correia (2003), Gottardo and Moisello (2014), López-Gracia and Sánchez- } \\
\text { Andújar (2007), Mishra and McConaughy (1999), Serrasqueiro et al. (2016) }\end{array}$ \\
\hline $\begin{array}{l}\text { Short-term debt } \\
\text { ratio }\end{array}$ & $D_{i t \text { st }}$ & $\frac{\text { Short term Liabilities }}{\text { Total Assets }}$ & Serrasqueiro et al. (2012), Thanh and Huong (2017) \\
\hline $\begin{array}{l}\text { Natural logarithm of } \\
\text { Debt-to-Equity ratio }\end{array}$ & $D_{i t \text { ln }}$ & $\ln \left(\frac{\text { Total Liabilities }}{\text { Equity }}\right)$ & López-Gracia and Sogorb-Mira (2008)
\end{tabular}

Source: Elaborated by the authors.

According to the assumptions of the TOT, the coefficient $\lambda$ must be quantified between 0 and 1 , while the adjustment costs must be inversely related to $\lambda$. If $\lambda>0$, the company adjusts, increasing or decreasing, the level of debt to the optimal; if $\lambda<1$, the company partially achieves the optimal, due to the positive transaction and adjustment costs.

To estimate the expression 2, it is important to find the optimum debt ratio. Not being directly observable, it becomes necessary to resort to a "proxy". Following the procedure of Fama and French (2002), López-Gracia and Sogorb-Mira (2008), Sogorb-Mira and López-Gracia (2003), and Serrasqueiro et al. (2012, 2016), the optimal debt ratio can be estimated through the financing determinants that, by empirical evidence from the TOT, affect the capital structure of the companies (equation 3):

$$
D_{i t}^{*}=\varphi_{0}+\sum_{k=1}^{m} \varphi_{k} Z_{k i t}+n_{i}+v_{i t}
$$

where $\varphi_{0}$ represents the regression's constant, $Z_{k i t}$ are the $m$ independent variables regarding company $i$ in period $t, \varphi_{\mathrm{k}}$ are the coefficients of each financing determinant $Z_{k}, n_{i}$ are the specific individual effects (which are not directly observable by the financing determinants) of each company $i$, and $v_{i t}$ is the term of random perturbation.

Once the optimal debt ratio has been defined, the partial adjustment model can be reached, considering the determinants that - in this theory - influence the financing decisions on the capital structure of the companies. Substituting the expression 3 in expression 2 and rearranging the terms, we obtain equation 4 :

$$
D_{i t}=\lambda \varphi_{0}+\delta D_{i t-1}+\sum_{k=1}^{m} \beta_{k} Z_{k i t}+\theta_{i}+\varepsilon_{i t}
$$

where $\delta=(1-\lambda), \beta_{k}=\left(\lambda \varphi_{k}\right), \theta_{i}=\left(\lambda n_{i}\right)$ and $\varepsilon_{i t}=\left(\lambda v_{i t}\right)$. Afterward, the determinants of funding and underlying research hypotheses are defined.

\subsubsection{Research hypotheses and variables}

The TOT expects companies to continuously adjust the actual debt ratio to an optimal level, where there is a trade-off between tax benefits and debt-related costs. However, when companies adjust the ratio, they support transaction costs that prevent a full debt adjustment to the optimal target (Acedo-Ramírez et al., 2017; Caetano, 2011; López-Gracia \& Sogorb-Mira, 2008; Serrasqueiro et al., 2016). In this context, the research hypotheses for Portuguese family enterprises are formulated:

$\mathrm{H}_{1}$ : Companies adjust the actual debt ratio to the optimal level.

$\mathrm{H}_{1.1}:$ High transaction costs keep companies away from the optimal level of indebtedness.

Despite the motivations for family companies to resort to debt as a form of monitoring, it is expected that greater convergence of interests and thus lower agency costs will improve the reputation recognized in the market and, consequently, the access to less burdensome debt. This leads to another research hypothesis (López-Gracia \& Sánchez-Andújar, 2007):

$\mathrm{H}_{1.2}$ : The family/company interaction implies lower agency costs in family businesses, facilitating the use of debt as a resource. This hypothesis is verified by the behavior of $\lambda$. 
It is now important to define the determinants of financing under the TOT's propositions (Adair \& Adaskou, 2015; Caetano, 2011; Frank \& Goyal, 2008, 2009; Serrasqueiro \& Caetano, 2015): effective tax rate, other non-debt tax shields, growth opportunities, profitability, size, age, and tangible assets. The signs of the expected

$$
D_{i t}=\delta D_{i t-1}+\beta_{0}+\beta_{1} E T R_{i t}+\beta_{2} N D T S_{i t}+\beta_{3} G O_{i t}+\beta_{4} P R O F_{i t}+\beta_{5} S I Z E_{i t}+\beta_{6} A G E_{i t}+\beta_{7} T A N G_{i t}+\theta_{i}+\varepsilon_{i t}
$$

where $E T R_{i t}$ is the effective tax rate of the company $i$ in period $t, N D T S_{i t}$ are the non-debt tax shields of the company $i$ in period $t, G O_{i t}$ are growth opportunities of the company $i$ in period $t, P R O F_{i t}$ is the profitability of the company $i$ in period $t, S I Z E_{i t}$ is the size of the company $i$ in period $t, A G E_{i t}$ is the company's age $i$ in period $t, T A N G_{i t}$ is the assets tangibility of the company $i$ in period $t$, the term $\theta_{i}$ represents the specific individual effects of each company $i$, and $\varepsilon_{i t}$ is the term of random perturbation.

\subsection{Testing the POT}

From the POT's perspective, companies use external financing only when internal resources are exhausted. In accordance with this, we followed the procedure described by Shyam-Sunder and Myers (1999). Here it is assumed relationship between the determinants of financing and debt are shown in Table 2.

The partial adjustment model, defined with the relevant financing determinants of the TOT, is expressed by equation 5 : that changes in debt are caused by the need for corporate funds, using a regression expressed by equation 6 :

$$
\Delta D_{i t}=\alpha+b_{P O} F D_{i t}+v_{i t}
$$

where $\Delta D_{i t}=D_{i t}-D_{i t-1}$ is the change in debt, $\alpha$ is the regression constant, $F D_{i t}$ is the financial deficit of the company $i$ in period $t, b_{P O}$ is the pecking order coefficient, and $v_{i t}$ is the error term.

The verification of the POT depends on the behavior of $\alpha$ and $b_{P O}$, which should equal 0 and 1, respectively (Shyam-Sunder \& Myers, 1999). To estimate the expression 6 , it is important to define the variable $F D_{i t}$, following the suggestion of López-Gracia and Sogorb-Mira (2008), Serrasqueiro et al. $(2012,2016)$, and Sogorb-Mira and López-Gracia (2003) (equation 7):

$$
F D_{i t}=\Delta \text { Fixed Assets }+\Delta \text { Working Capital }+\Delta \text { Long term Debt }-C F
$$

where $\Delta$ Fixed Assets $=$ Fixed Assets $_{t}-$ Fixed Assets ${ }_{t-1}$, $\Delta$ Working Capital $=$ Working Capital - - Working Capital ${ }_{t-1}$, $\Delta$ Long term Debt $=$ Long term Debt $t_{t}-$ Long term Deb $_{t-1}$, and $C F=$ Cash Flow $=$ Net Profit + Depreciation + Amortization.

In the search for robust results, the POT is also tested through a regression between indebtedness and the determinants of corporate financing. Subsequently, the determinants of funding and the underlying research hypotheses are defined.

\subsubsection{Research hypotheses and variables}

The POT provides for companies to use internal funds as the primary form of financing. However, when these funds are insufficient to meet the needs, companies seek, first and foremost, to issue debt and, as a last resort, to issue shares. In this context, the following research hypothesis is formulated for Portuguese family companies (ShyamSunder \& Myers, 1999):

$\mathrm{H}_{2}$ : The change in corporate debt is justified by the deficit of funds. This hypothesis is verified by the behavior of $\alpha$ and $b_{P O}$.
It is important now to define the determinants of financing under the POT proposals (López-Gracia \& Sánchez-Andújar, 2007; López-Gracia \& Sogorb-Mira, 2008; Serrasqueiro et al., 2011; Sogorb-Mira \& LópezGracia, 2003): cash flow, age, the relationship between cash flow and growth opportunities. The signs of the expected relationship between the determinants of financing and debt are shown in Table 2.

López-Gracia and Sogorb-Mira (2008) point out that the variables cash flow and growth opportunities should not be used separately, since the interaction between the two influences financing decisions. Thus, these hypotheses are also added:

$\mathrm{H}_{2 \mathrm{a}-1}$ : There is a positive relationship between debt and high growth opportunities with low cash flows.

$\mathrm{H}_{2 \mathrm{a}-2}$ : There is a negative relationship between debt and reduced growth opportunities with high cash flows.

The model, for the relationship between the debt and the relevant financing determinants of the POT, is expressed by equation 8 :

$$
D_{i t}=\alpha+\beta_{1} C F_{i t}+\beta_{2} A G E_{i t}+\beta_{3} H G O L C F_{i t}+\beta_{4} L G O H C F_{i t}+n_{i}+v_{i t}
$$

where $C F_{i t}$ is the cash flow of the company $i$ in period $t$, $H G O L C F_{i t}$ and $L G O H C F_{i t}$ are the growth opportunities of the company $i$ in period $t$ (corresponding to situations of high growth opportunities with low cash flows, 
and situations of low growth opportunities with high cash flows, respectively), $n_{i}$ are the specific individual effects of company $i$, and $v_{i t}$ is the term of random perturbation.

Table 2

Description of the independent variables

\begin{tabular}{|c|c|c|c|c|}
\hline $\begin{array}{l}\text { Independent } \\
\text { variable }\end{array}$ & Notation & Proxy & $\begin{array}{l}\text { Expected } \\
\text { Sign }\end{array}$ & Authors \\
\hline $\begin{array}{l}\text { Effective tax } \\
\text { rate }\end{array}$ & ETR & $\frac{\text { Income Tax Expenses }}{E B T}$ & + & $\begin{array}{l}\text { Caetano (2011), } \\
\text { López-Gracia and Sánchez-Andújar (2007), López-Gracia } \\
\text { and Sogorb-Mira (2008), Serrasqueiro and Caetano (2015), } \\
\text { Serrasqueiro and Nunes (2010), Serrasqueiro et al. (2011, } \\
\text { 2012, 2016), Sogorb-Mira and López-Gracia (2003) }\end{array}$ \\
\hline \multirow{4}{*}{$\begin{array}{l}\text { Non debt } \\
\text { tax shields }\end{array}$} & $\begin{array}{l}\text { NDTS } \\
(1)\end{array}$ & $\frac{\text { Depreciation }+ \text { Amortization }}{\text { Total Assets }}$ & - & $\begin{array}{c}\text { Caetano (2011), Dang (2005), Fama and French (2002), } \\
\text { Keasey et al. (2015), López-Gracia and Sánchez- } \\
\text { Andújar (2007), López-Gracia and Sogorb-Mira (2008), } \\
\text { Serrasqueiro et al. (2012, 2016), Sogorb-Mira and López- } \\
\text { Gracia (2003) }\end{array}$ \\
\hline & $\begin{array}{l}\text { NDTS } \\
(2)\end{array}$ & $\frac{\text { Depreciation }+ \text { Amortization }}{E B I T D A}$ & - & Ramalho and Silva (2009) \\
\hline & $\begin{array}{l}\text { NDTS } \\
(3)\end{array}$ & $\frac{\text { EBIT - Interest Expenses - Income Tax Expenses }}{\text { Sales }}$ & - & Vieira (2014) \\
\hline & $\begin{array}{l}\text { NDTS } \\
(4)\end{array}$ & $\frac{\text { Depreciation }+ \text { Amortization }}{E B I T}$ & - & Correia (2003) \\
\hline \multirow{4}{*}{$\begin{array}{l}\text { Growth } \\
\text { opportunities }\end{array}$} & $\mathrm{GO}(1)$ & 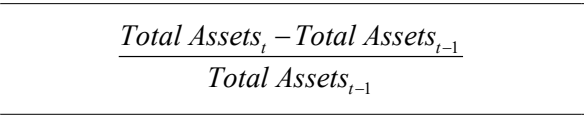 & - & $\begin{array}{c}\text { Ramalho and Silva (2009), Serrasqueiro et al. (2011, } \\
\text { 2012), Thanh and Huong (2017), } \\
\text { Tong and Green (2005), }\end{array}$ \\
\hline & $\mathrm{GO}(2)$ & $\frac{\text { Intangible Assets }}{\text { Total Asset }}$ & - & $\begin{array}{l}\text { Acedo-Ramírez et al. (2017), Adair and Adaskou (2015), } \\
\text { Caetano (2011), Sogorb-Mira and López-Gracia (2003) }\end{array}$ \\
\hline & $\mathrm{GO}(3)$ & $\frac{\text { Sales }_{t}-\text { Sales }_{t-1}}{\text { Sales }_{t-1}}$ & - & $\begin{array}{c}\text { López-Gracia and Sánchez-Andújar (2007), López-Gracia } \\
\text { and Sogorb-Mira (2008) }\end{array}$ \\
\hline & $\mathrm{GO}(4)$ & 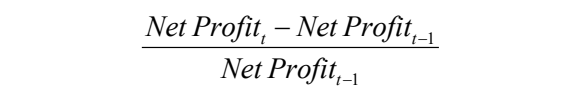 & - & Setia-Atmaja et al. (2009) \\
\hline \multirow{5}{*}{ Profitability } & $\begin{array}{l}\text { PROF } \\
(1)\end{array}$ & $\frac{E B I T}{\text { Total Assets }}$ & + & $\begin{array}{l}\text { Dang (2005), Fama and French (2002), López-Gracia } \\
\text { and Sánchez-Andújar (2007), López-Gracia and Sogorb- } \\
\text { Mira (2008), Ramalho and Silva (2009), Serrasqueiro and } \\
\text { Caetano (2015), Serrasqueiro et al. (2011, 2012, 2016), } \\
\text { Sogorb-Mira and López-Gracia (2003), Vieira (2014) }\end{array}$ \\
\hline & $\begin{array}{l}\text { PROF } \\
(2)\end{array}$ & $\frac{E B T}{\text { Total Assets }}$ & + & Thanh and Huong (2017) \\
\hline & $\begin{array}{l}\text { PROF } \\
(3)\end{array}$ & $\frac{E B I T}{\text { Sales }}$ & + & Rita (2011), Serrasqueiro et al. (2016) \\
\hline & $\begin{array}{l}\text { PROF } \\
(4)\end{array}$ & $\frac{\text { EBITDA }}{\text { Total Assets }}$ & + & Ampenberger et al. (2013) \\
\hline & $\begin{array}{l}\text { PROF } \\
(5)\end{array}$ & $\frac{\text { Net Profit }}{\text { Total Asset }}$ & + & Correia (2003) \\
\hline
\end{tabular}

SIZE (1)

Size
Table 2 details the proxies used by the literature to represent the financing determinants associated with the independent variables of the TOT model and the POT models: 
Table 2

Cont.

\begin{tabular}{|c|c|c|c|c|}
\hline $\begin{array}{l}\text { Independent } \\
\text { variable }\end{array}$ & Notation & Proxy & $\begin{array}{l}\text { Expected } \\
\text { Sign }\end{array}$ & Authors \\
\hline \multirow[t]{2}{*}{ Age } & AGE (1) & $\ln ($ number of years of life) & $+/-$ & $\begin{array}{l}\text { Acedo-Ramírez et al. (2017), Ampenberger et al. (2013), } \\
\text { Keasey et al. (2015), López-Gracia and Sánchez- } \\
\text { Andújar (2007), López-Gracia and Sogorb-Mira (2008), } \\
\text { Serrasqueiro et al. (2016), Setia-Atmaja et al. (2009), } \\
\text { Sogorb-Mira and López-Gracia (2003), Vieira (2014) }\end{array}$ \\
\hline & AGE (2) & number of years of life & $+/-$ & $\begin{array}{l}\text { Adair and Adaskou (2015), Croci et al. (2011), Ramalho } \\
\text { and Silva (2009) }\end{array}$ \\
\hline \multirow[t]{2}{*}{$\begin{array}{l}\text { Assets } \\
\text { tangibility }\end{array}$} & $\begin{array}{l}\text { TANG } \\
(1)\end{array}$ & $\frac{\text { Fixed Assets }}{\text { Total Assets }}$ & + & $\begin{array}{c}\text { Correia (2003), Croci et al. (2011), Dang (2005), Ellul } \\
\text { (2008), Gottardo and Moisello (2014), Mishra and } \\
\text { McConaughy (1999), Serrasqueiro and Caetano (2015), } \\
\text { Serrasqueiro et al. (2012, 2016), Setia-Atmaja et al. } \\
\text { (2009), Thanh and Huong (2017) }\end{array}$ \\
\hline & $\begin{array}{l}\text { TANG } \\
(2)\end{array}$ & $\frac{\text { Fixed Assets }+ \text { Inventories }}{\text { Total Assets }}$ & + & $\begin{array}{l}\text { Adair and Adaskou (2015), Ramalho and Silva (2009), } \\
\text { Sogorb-Mira and López-Gracia (2003) }\end{array}$ \\
\hline \multirow{5}{*}{ Cash flow } & CF (1) & $\frac{\text { EBIT }+ \text { Depreciation }+ \text { Amortization }}{\text { Total Assets }}$ & - & López-Gracia and Sánchez-Andújar (2007) \\
\hline & CF $(2)$ & $\frac{\text { EBIT }+ \text { Depreciation }+ \text { Amortization }}{\text { Fixed Assets }}$ & - & Sogorb-Mira and López-Gracia (2003) \\
\hline & CF (3) & $\frac{\text { Net Profit }+ \text { Depreciation }+ \text { Amortization }}{\text { Total Assets }}$ & - & Keasey et al. (2015), Serrasqueiro et al. (2011), \\
\hline & CF (4) & Net Profit + Depreciation + Amortization & - & López-Gracia and Sogorb-Mira (2008) \\
\hline & CF (5) & $\frac{\text { EBIT }+(\text { Depreciation }+ \text { Amortiz. }+ \text { Provisions })}{\text { Total Assets }}$ & - & Acedo-Ramírez et al. (2017) \\
\hline $\begin{array}{l}\text { Relationship } \\
\text { between } \\
\text { growth } \\
\text { opportunities } \\
\text { and cash } \\
\text { flow }\end{array}$ & $\begin{array}{l}\text { HGOLCF } \\
\text { and } \\
\text { LGOHCF }\end{array}$ & Conditional Dummy Variables & + & $\begin{array}{l}\text { López-Gracia and Sánchez-Andújar (2007), López-Gracia } \\
\text { and Sogorb-Mira (2008), Serrasqueiro et al. (2011) }\end{array}$ \\
\hline
\end{tabular}

$E B I T=$ earnings before interest and taxes; EBITDA = earnings before interest, taxes, depreciation, and amortization;

$E B T=$ earnings before taxes.

Source: Elaborated by the authors.

To determine the variables $H G O L C F_{i t}$ and $L G O H C F_{i t}$ in two steps, the dummy variables are initially used (Table 3 ).

Table 3

Description of the dummy variables

\begin{tabular}{ll}
\hline 1 & $\begin{array}{l}\text { For companies that, at any given time, present } \\
\text { simultaneously growth opportunities above the average of } \\
\text { the total sample and cash flows below the average of the } \\
\text { total sample. }\end{array}$ \\
\hline $0 \quad$ Other situations. \\
\hline $1 \quad \begin{array}{l}\text { For companies that, at any given time, exhibit } \\
\text { simultaneously growth opportunities below the average of } \\
\text { the total sample and cash flows above the average of the } \\
\text { total sample. }\end{array}$ \\
\hline $0 \quad$ Other situations.
\end{tabular}

Source: Elaborated by the authors.
Subsequently, the variables $H G O L C F_{i t}$ and $L G O H C F_{i t}$ are calculated multiplying the previous dummy variable by the proxy of growth opportunities.

\subsection{Conjoint Test}

Testing both the TOT and the POT aims to identify which of the theories of capital structure explains better performance in the Portuguese family businesses. The study considers the partial adjustment model and the model of Shyam-Sunder and Myers (1999), following the procedure of Serrasqueiro and Nunes (2010). Adding the expressions 1 and 6 , we have equation 9 :

$$
D_{i t}-D_{i t-1}=\lambda\left(D_{i t}^{*}-D_{i t-1}\right)+\alpha+b_{P O} F D_{i t}+v_{i t}
$$


Including in the expression 9 the determinants of the TOT and POT financing, the joint test model is given by equation 10 :

$$
D_{i t}=\alpha+\delta D_{i t-1}+b_{P O} F D_{i t}+\sum_{k=1}^{m} \beta_{k} Z_{k i t}+\theta_{i}+\varepsilon_{i t}
$$

$$
\begin{gathered}
D_{i t}=\alpha+\delta D_{i t-1}+b_{P O} F D_{i t}+\beta_{1} E T R_{i t}+\beta_{2} N D T S_{i t}+\beta_{3} G O_{i t}+\beta_{4} P R O F_{i t}+ \\
\beta_{5} S I Z E_{i t}+\beta_{6} A G E_{i t}+\beta_{7} T A N G_{i t}+\beta_{8} C F_{i t}+\beta_{9} H G O L C F_{i t}+\beta_{10} L G O H C F_{i t}+\theta_{i}+\varepsilon_{i t}
\end{gathered}
$$

where $\alpha$ is a regression constant, $\theta_{i}$ are the specific individual effects of each company $i$, and $\varepsilon_{i t}$ is the term of random perturbation.

\subsubsection{Research hypotheses}

To carry out the joint test, the research hypotheses formulated by Serrasqueiro and Nunes (2010) are replicated:
$\mathrm{H}_{3}$ : If $b_{P O} \neq 0$ and $\lambda \neq 0$, the TOT and the POT are not mutually exclusive.

$\mathrm{H}_{4}$ : If $\lambda>b_{P O}$, corporate financing decisions are closer to the assumptions of the TOT than to the assumptions of the POT.

$\mathrm{H}_{5}$ : If $b_{P O}>\lambda$, corporate financing decisions are closer to the assumptions of the POT than to the assumptions of the TOT.

\section{SAMPLE AND DATA}

\subsection{Selection Process}

Considering the scarcity of information on succession issues, this study follows the criterion of ownership to identify family businesses, more specifically, the reference proposed by López-Gracia and Sánchez-Andújar (2007, p. 276): "We considered all those businesses with a shareholder (single or family) owning more than $50 \%$ and the rest of the shares being relatively diluted as a family firm." The selection of Portuguese family companies used the SABI database (https://sabi.bvdinfo.com - The Iberian Balance Sheet Analysis System is managed by
Informa SA and Bureau van Dijk). Although it does not report on the participation of the family members in the management of the companies, it indicates the distribution of the capital of the companies, allowing the selection of those that have characteristics of family property. In addition, information was extracted on the respective financial statements and concentration of capital.

Of the 605,724 companies in Portugal, 4,952 small, medium, and large family companies were selected in the period between 2009 and 2016, according to the filters shown in the Table 4.

\section{Table 4}

Sample constitution

\begin{tabular}{ll}
\hline Restrictions & $\begin{array}{c}\text { Sample } \\
\text { (n. companies) }\end{array}$ \\
\hline Portuguese companies & 605,724 \\
\hline Active companies & 332,874 \\
\hline Corporations and limited liability companies & 330,345 \\
\hline Non-financial corporations & 319,138 \\
\hline Individual or family controls more than 50\% of the property & 284,188 \\
\hline Present accounts for the period 2009-2016 & 57,936 \\
\hline Positive equity & 39,713 \\
\hline Small, medium, and large family businesses & 4,952 \\
\hline
\end{tabular}

Note: Decree-Law n. 98. (2015, June 2) classifies as micro-entities companies that do not exceed two of the three limits: $€ 350,000$ in balance sheet, $€ 700,000$ in net business, and 10 employees (on average) during the period. The exclusion of the micro-entities from the sample was due to the low bargaining power in access to credit, being very conditioned to the rules of the financial market. Consequently, their contribution would be reduced in order to analyze the financing choices of family businesses, which is the main objective of this study.

Source: Elaborated by the authors. 


\subsection{Selection of Proxies for Models}

The choice of the most appropriate proxies for each capital structure theory was based on the weighting of several criteria: the results of the Pearson correlation matrices [this information with the significance levels for the determinants of TOT and POT financing and for the Shyam-Sunder and Myers (1999) model variables can be made available upon request to the authors]; the simulation of estimates on multiple specifications in the TOT model and the POT model, with the dependent variable defined by the $D_{i t}$ ratio, the $D_{i t s t}$ ratio, and the $D_{i t l n}$ ratio; the underlying tests of individual significance and global significance, using the $t$ Student statistic and the Fisher-Snedecor F statistic, respectively; the underlying analyzes of the quality of adjustment of the regression models, through the determination coefficients $R^{2}$.

For the determinants of financing of the TOT in the partial adjustment model, the non-debt tax shields [NDTS (1)], growth opportunities [GO (1)], profitability [PROF (2)], size [SIZE (1)], age [AGE (1)], and assets tangibility [TANG (2)] proxies were those that estimated the best structures for the dependent variables total debt $\left(D_{i t}\right)$ and debt-to-equity $\left(D_{i t l_{n}}\right)$. For the dependent variable shortterm debt $\left(D_{i t s t}\right)$, the same proxies were selected, with the exception of GO (1) and TANG (2), which were replaced by GO (2) and TANG (1), respectively. The effective tax rate (ETR) variable was maintained in the model, despite the low statistical significance, because its relationship with the dependent variables is important for this study.

For the model of the determinants of financing of the POT, cash flow [CF (3)] and AGE (1) proxies estimated the best structure for all dependent variables. It should be noted that the inclusion of the GO variable was due to the need to determine the dummy variable growth opportunities above the average of the total sample and cash flows below the average of the total sample (HGOLCF) and the dummy variable growth opportunities below the average of the total sample and cash flows above the average of the total sample (LGOHCF). Although the GO (2) proxy has greater significance in the model whose dependent variable is $D_{i t s t}$, the HGOLCF and LGOHCF variables were calculated for all models through the proxies CF (3) and GO (1) because, in addition to facilitating the calculation, $\mathrm{GO}(1)$ and $\mathrm{GO}(2)$ have similar statistical significance.

\subsection{Descriptive Statistics}

Table 5 presents the descriptive statistics of the proxies selected for the study, whose sample includes 39,616 observations.

Table 5

Descriptive statistics of the variables $(n=39,616)$

\begin{tabular}{|c|c|c|c|c|c|}
\hline Variable & Notation & Mean & $\begin{array}{l}\text { Standard } \\
\text { deviation }\end{array}$ & Minimum & Maximum \\
\hline Total debt ratio & $\mathrm{D}_{\mathrm{it}}$ & 0.553 & 0.2272 & 0 & 2.9982 \\
\hline Short-term debt ratio & $D_{\text {it st }}$ & 0.4161 & 0.2149 & 0 & 2.35 \\
\hline \multirow[t]{4}{*}{ Natural logarithm of debt-to-equity ratio } & $D_{i t \ln }$ & 0.2392 & 1.1408 & -8.0889 & 9.0037 \\
\hline & $\Delta \mathrm{D}_{\mathrm{it}}$ & -0.0159 & 0.1043 & -2.6693 & 2.9241 \\
\hline & $\Delta D_{\text {it st }}$ & -0.0145 & 0.1408 & -1.5003 & 1.6395 \\
\hline & $\Delta D_{i t \ln }$ & -0.0696 & 0.4337 & -7.6658 & 9.4695 \\
\hline Financial deficit & FD & -0.0027 & 0.2938 & -35.9465 & 26.4694 \\
\hline Effective tax rate & ETR & 0.3223 & 3.5902 & -106.6051 & 362.4484 \\
\hline Non debt tax shields & NDTS (1) & 0.0381 & 0.0376 & -0.1781 & 0.8075 \\
\hline \multirow{2}{*}{ Growth opportunities } & $\mathrm{GO}(1)$ & 0.0481 & 0.3299 & -0.8622 & 49.8082 \\
\hline & GO (2) & 0.0102 & 0.0625 & -0.0074 & 0.9198 \\
\hline Profitability & PROF (2) & 0.0463 & 0.0822 & -3.1495 & 0.9055 \\
\hline Size & SIZE (1) & 7.5911 & 0.9978 & -0.0174 & 13.6302 \\
\hline Age & AGE (1) & 2.967 & 0.6127 & 0 & 4.727 \\
\hline \multirow{2}{*}{ Assets tangibility } & TANG (1) & 0.2478 & 0.2103 & 0 & 1.0211 \\
\hline & TANG (2) & 0.4196 & 0.2402 & 0 & 1.1197 \\
\hline Cash flow & CF (3) & 0.0716 & 0.0859 & -3.1710 & 4.7425 \\
\hline \multirow{2}{*}{$\begin{array}{l}\text { Relationship between growth } \\
\text { opportunities and cash flow }\end{array}$} & HGOLCF & 0.0433 & 0.2917 & 0 & 49.8082 \\
\hline & LGOHCF & -0.0126 & 0.0507 & -0.7857 & 0.0846 \\
\hline
\end{tabular}

Notes: The variables are described in tables 1, 2 and 3.

Source: Elaborated by the authors. 
$D_{i t}$ is the dependent variable with a higher mean value, followed by $D_{i t s t}$ and $D_{i t l n}$. These variables present negative mean variations, being the $\Delta D_{i t \ln }$ more expressive.

Among the determinants of financing of the TOT in the partial adjustment model, we highlight SIZE (1) and AGE (1) with higher mean values. Also with respect to the independent variables in the same model, we highlight ETR, GO (1), GO (2), and PROF (2) due to marked volatility, with a standard deviation (SD) above the mean.

The variable financial deficit (FD), in the model proposed by Shyam-Sunder and Myers (1999), has negative mean value, meaning that Portuguese family companies generated surplus funds during the period under analysis and justified the negative variations on the debt ratios. However, this variable assumes a SD above the mean.

In the model of determinants of financing of the POT, the variable AGE (1) presents the upper average value and the variable LGOHCF presents negative average value. However, the variables CF (3), HGOLCF, and LGOHCF assume marked volatility.

\section{RESULTS AND DISCUSSION}

\subsection{TOT Test}

\subsubsection{Adjustment of the actual level of debt to the target}

Table 6 presents the results for the partial adjustment model, expressed in the equation 5 , of the actual level of debt towards the optimum target level and for the relationship between the financing determinants and the dependent variables representing the indebtedness. That model includes the lagged variable $D_{i t-1}$, making it impossible to use the OLS estimator due to the correlation of this independent variable with the individual (unobservable) effects $n_{i}$ and with the error term $v_{i t}$. Consequently, the GMM system estimator of Blundell and Bond (1998), which is more efficient than the GMM estimator of Arellano and Bond (1991), was used because the estimation of the coefficients of the model takes into account the existence of autocorrelation by the presence of the lagged variable and the heterogeneity represented by the individual effects of the panel (Baltagi, 2005).

Table 6

Partial adjustment model

\begin{tabular}{|c|c|c|c|}
\hline \multirow{2}{*}{ Independent variables } & \multicolumn{3}{|c|}{ Dependent variables } \\
\hline & $D_{i t}$ & $D_{\text {it st }}$ & $D_{i t \ln }$ \\
\hline$D_{i t-1}$ & $0.5166^{* * *}$ & & \\
\hline$D_{i t-1 s t}$ & & $0.4824^{* * *}$ & \\
\hline$D_{i t-1 / n}$ & & & $0.8137^{* * *}$ \\
\hline$\lambda$ & $0.4834^{* * *}$ & $0.5176^{* * *}$ & $0.1863^{* * *}$ \\
\hline ETR & -0.00004 & -0.00002 & -0.0007 \\
\hline NDTS (1) & $0.2249^{* * *}$ & $0.2071^{* * *}$ & $0.2335^{* * *}$ \\
\hline $\mathrm{GO}(1)$ & $0.1022^{* * *}$ & & $0.6727^{* * *}$ \\
\hline GO (2) & & $-0.1226^{* * *}$ & \\
\hline PROF (2) & $-0.6016^{* * *}$ & $-0.3832^{* * *}$ & $-2.3287^{* * *}$ \\
\hline SIZE (1) & $0.0387^{* * *}$ & $0.0360^{* * *}$ & $0.0293^{* * *}$ \\
\hline AGE (1) & $-0.0164 * * *$ & $-0.0142^{* * *}$ & $-0.0552^{* * *}$ \\
\hline TANG (1) & & $-0.0665^{* * *}$ & \\
\hline TANG (2) & $0.0591^{* * *}$ & & -0.0049 \\
\hline Hansen & $1,091.01^{* * *}$ & $702.41^{* * *}$ & $293.78^{* * *}$ \\
\hline$m_{1}$ & $-10.15^{* * *}$ & $-15.06^{* * *}$ & $-11.05^{* * *}$ \\
\hline$m_{2}$ & $9.93 * * *$ & $8.10^{* * *}$ & $6.96^{* * *}$ \\
\hline Wald $\left(\chi^{2}\right)$ & $174.272^{* * *}$ & $92,636.79^{* * *}$ & $22,967.57^{* * *}$ \\
\hline N. obs. & 39,616 & 39,616 & 39,616 \\
\hline
\end{tabular}

Notes: The variables are described in tables 1,2 and 3. Hansen test has as $H_{0}$ the validation of the restrictions imposed by the use of instruments; $m_{1}$ and $m_{2}$ represent the first and second order autocorrelation tests, respectively, having as $H_{0}$ the absence of autocorrelation; the Wald test follows a $\chi^{2}$ distribution and has as $H_{0}$ that the independent variables, globally, do not explain the dependent variable.

${ }^{*}=p$-value $<0.1 ;{ }^{* *}=p$-value $<0.05 ;{ }^{* * *}=p$-value $<0.01$.

Source: Elaborated by the authors. 
The results of the Hansen test are statistically significant at $1 \%$, suggesting the rejection of $\mathrm{H}_{0}$, and thus the restrictions imposed by the use of instruments are not valid, pointing to an over-identification of the restrictions. In addition, the results of the autocorrelation test are also significant at $1 \%$, suggesting the rejection of $\mathrm{H}_{0}$ and thus confirming first and second order autocorrelation in the models, which validates the need to use GMM dynamic models. Given the non-validity of the instruments, we conclude that the results obtained by the GMM system estimator are not considered robust. However, the values of the Wald test are relevant at $1 \%$, proposing the rejection of $\mathrm{H}_{0}$ and thus the independent variables - taken globally - are significant to explain the dependent variables.

The empirical results of the partial adjustment model show that the rate of adjustment of short-term debt $(\lambda=0.5176)$ towards the optimal ratio is relatively higher than the rate of adjustment of total debt $(\lambda=0.4834)$ and much higher than the rate of debt-to-equity adjustment $(\lambda=0.1863)$. This evidence allows us to validate $H_{1}$ that companies adjust the actual debt ratio to the optimal level, in that the estimates of the coefficients $\lambda$ are positive.
Even so, these estimates are less than 1, indicating that Portuguese family companies face transaction costs that keep them away from the optimal debt level (Myers, 1984), and can be accepted as $\mathrm{H}_{1.1}$. This evidence converges with the studies of López-Gracia and Sánchez-Andújar (2007), on Spanish family companies, Bauweraerts and Colot (2012), on Belgian family companies, and Serrasqueiro et al. $(2012,2016)$, in reference to the Portuguese family businesses.

In the context of family businesses, it is anticipated that reduced agency costs, given the family/business interaction, will result in higher levels of reputation and, consequently, easier access to indebtedness. The results obtained by the coefficient $\lambda$, in relation to total debt and short-term debt, suggest that companies have some difficulty in adjusting the level of indebtedness to the optimal level, thus the $\mathrm{H}_{1.2}$ can be accepted.

\subsubsection{Determinants of financing}

Table 7 summarizes the test results to the TOT using the partial debt adjustment model, considering that the optimal level depends on the financing determinants.

Table 7

Verification of the trade-off theory (TOT) research assumptions

\begin{tabular}{lccc}
\hline Independent variables & $\begin{array}{c}\text { Expected } \\
\text { relationship }\end{array}$ & $\begin{array}{c}\text { Estimated } \\
\text { relationship }\end{array}$ & $\begin{array}{c}\text { Validation of hypotheses or } \\
\text { relationship }\end{array}$ \\
\hline$\lambda$ & $\lambda>0$ & $\lambda>0$ & $\mathrm{H}_{1}:$ Validated \\
\hline$(1-\lambda)$ & $(1-\lambda)>0$ & $(1-\lambda)>0$ & $\mathrm{H}_{1.1}:$ Validated \\
\hline Agency costs & & & $\mathrm{H}_{1.2}:$ Validated \\
\hline ETR & + & n.s. & Rel. not validated \\
\hline NDTS & - & + & Rel. not validated \\
\hline GO & - & $+/-$ & Rel. not validated \\
\hline PROF & + & - & Rel. not validated \\
\hline SIZE & + & + & Rel. validated \\
\hline AGE & + & - & Rel. not validated \\
\hline TANG & + & $+/$-/n.s. & Rel. not validated \\
\hline
\end{tabular}

Notes: The variables are described in tables 1, 2 and 3.

n.s. = non-significant.

Source: Elaborated by the authors.

Contrary to what was expected, there was a negative but not significant relationship between ETR and debt in its three proxies. This suggests that Portuguese family businesses do not take advantage of the tax benefits of interest, derived from increasing debt, indicating the rejection of expected relationship sign. In the NDTS, there were positive relationships, significant at $1 \%$, with the three debt proxies. Contrary to what was expected, Portuguese family companies do not reduce the use of credit when they are able to enjoy non-debt tax shields, suggesting the rejection of expected relationship sign.
The positive, statistically relevant, relationship of the GO with the dependent variables $D_{i t}$ and $D_{i t l n}$ does not allow the expected relationship sign to be accepted, despite the strong negative relation with the dependent variable $D_{i t s t}$. This evidence suggests that, given growth opportunities, Portuguese family businesses reduce shortterm debt and increase medium and long-term debt. The significant negative relationship between PROF and the dependent variables does not allow us to accept expected relationship sign. Moreover, this result converges with the assumptions of the POT, in which the companies start 
to resort to self-financing and only when the internal resources run out, will they resort to external capital. The variable SIZE obtained a positive relationship, significant at $1 \%$, with the dependent variables, corroborating the expected relationship sign. This means that Portuguese family businesses with a larger size (and market position, in terms of image and reputation) face less likelihood of insolvency and less amount of asymmetric information, ensuring more trust with creditors and facilitating more debt. The important negative relationship between AGE and debt proxies does not allow us to accept expected relationship sign. In addition, this result converges with the POT, where older companies tend to accumulate more profit and, consequently, use less debt. Finally, the significant positive relationship between the variable TANG and $D_{i t}$ allows us to accept the expected relationship sign. However, there is a significant negative relationship with $D_{i t s t}$ and not significant with $D_{i t l n}$. This suggests that
Portuguese family businesses use the value of tangible assets as warranty for obtaining credit, mainly in longer maturities.

\subsection{POT Test}

\subsubsection{Relationship between the financing deficit and the variation in indebtedness}

Table 8 presents the results for the model proposed by Shyam-Sunder and Myers (1999), expressed in equation 6, in regard to the impact of the financial deficit on the variation of the dependent variables representing debt. The estimation of this model resorted to an OLS regression, since the dependent variable is presented by the first differences and, therefore, the individual (unobservable) effects of the companies become irrelevant, being eliminated in the model.

\section{Table 8}

Impact of the financial deficit on changes in indebtedness

\begin{tabular}{|c|c|c|c|}
\hline \multirow{2}{*}{ Independent variables } & \multicolumn{3}{|c|}{ Dependent variables } \\
\hline & $\Delta \mathrm{D}_{\mathrm{it}}$ & $D_{\text {it st }}$ & $\Delta \mathbf{D}_{\mathrm{it} \ln }$ \\
\hline$\alpha$ & $-0.0155^{* * *}$ & $-0.0146^{* * *}$ & $-0.0697^{* * *}$ \\
\hline $\mathrm{FD}$ & $0.1614^{* * *}$ & $-0.0197 * * *$ & -0.0100 \\
\hline$R^{2}$ & 0.0087 & 0.0017 & 0.00005 \\
\hline$R_{A d j}^{2}$ & 0.0086 & 0.0017 & 0.00002 \\
\hline $\mathrm{F}$ & $345.9^{* * *}$ & $67.23^{* * *}$ & 1.83 \\
\hline N. obs. & 39,616 & 39,616 & 39,616 \\
\hline
\end{tabular}

Note: The variables are described in tables 1, 2 and 3. F test has as $H_{0}$ the statistical insignificance of the set of independent variables.

${ }^{*}=p$-value $<0.1 ; * *=p$-value $<0.05 ; * * *=p$-value $<0.01$.

Source: Elaborated by the authors.

The regressions of the Shyam-Sunder and Myers model present estimates close to 0 for parameter $\alpha$, converging with what was predicted by the POT, and for parameter $b_{P O}$, diverging from the predictions. Generally, the $b_{P O}$ results indicate that the marginal increase in the financial deficit has no impact on indebtedness. However, we can observe a significant positive relationship between the FD and the total debt change $\left(\Delta D_{i t}\right)$ and a significant negative relation between the FD and the short-term debt variation $\left(\Delta D_{i t s t}\right)$.

The Fisher-Snedecor F test confirms that the independent variable FD is only significant at $1 \%$ in the model $\Delta D_{i t}$ and in the model $\Delta D_{i t s t}$. The reduced coefficients of determination, $R^{2}$ and $R^{2}{ }_{A d j}$, justify the low explanatory power of any of the models, represented by the three debt proxies, at the expense of the FD variable.

It seems that the low proportion of debt financing in relation to the deficit of funds corresponds to the portion of capital obtained to meet the needs not covered by the internal resources of Portuguese family enterprises, contrary to the assumptions of the POT and the acceptance of $\mathrm{H}_{2}$. These evidences diverge from the expected, considering the study of Serrasqueiro et al. (2012, 2016), on Portuguese family businesses, and the study of Bauweraerts and Colot (2012), on Belgian family companies, although they converge with the study of Sogorb-Mira and López-Gracia (2003) on Spanish SMEs.

\subsubsection{Determinants of financing}

Table 9 presents the estimates of the relationship between the debt proxies and the financing determinants in the POT, expressed in equation 8 , using static panel models: an OLS regression, a fixed effects model, and a random effects model, respectively. To identify the most appropriate form of estimation, we used the results of the Breusch-Pagan Lagrange multiplier (LM) test and 
the Hausman test. Since heteroskedasticity is a common phenomenon in studies that use cross-sectional data, the fixed effects model and the random effects model were computed using the White (1980) estimator. This estimator determines the same results as the traditional estimator for the coefficients, although the standard error, and thus, the level of significance of the $t$ Student test considers possible heteroskedasticity (Murteira et al., 2016).

Table 9

Determinants of financing in the pecking order theory (POT)

\begin{tabular}{|c|c|c|c|}
\hline \multirow{2}{*}{ Independent variables } & \multicolumn{3}{|c|}{ Dependent variable: $D_{i t}$} \\
\hline & OLS & Fixed effects & Random effects \\
\hline$\alpha$ & $0.81 * * *$ & $1.1101^{* * *}$ & $1.0225^{* * *}$ \\
\hline CF (3) & $-0.5545^{* * *}$ & $-0.2750 * * *$ & $-0.288^{* * *}$ \\
\hline AGE (1) & $-0.0747^{* * *}$ & $-0.1812^{* * *}$ & $-0.1514^{* * *}$ \\
\hline HGOLCF & $0.0525^{* * *}$ & 0.0147 & 0.0164 \\
\hline LGOHCF & $-0.1689 * * *$ & 0.0172 & 0.0110 \\
\hline $\mathrm{R}^{2}$ & 0.0778 & 0.1322 & 0.1127 \\
\hline$R_{\text {Adj }}^{2}$ & 0.0777 & 0.0082 & 0.1126 \\
\hline $\mathrm{F}$ & $835.17^{* * *}$ & $1,320.52^{* * *}$ & $1,257.75^{* * *}$ \\
\hline $\operatorname{LM}\left(\chi^{2}\right)$ & & $89,119^{* * *}$ & \\
\hline Hausman $\left(\chi^{2}\right)$ & & $746.91^{* * *}$ & \\
\hline \multirow[t]{2}{*}{ N. obs. } & 39,616 & 39,616 & 39,616 \\
\hline & \multicolumn{3}{|c|}{ Dependent variable: $D_{i t s t}$} \\
\hline$\alpha$ & $0.6255^{* * *}$ & $0.9430^{* *}$ & $0.8026^{* * *}$ \\
\hline CF (3) & $-0.3671^{* * *}$ & $-0.1525^{* * *}$ & $-0.1703^{* * *}$ \\
\hline AGE (1) & $-0.0630 * * *$ & $-0.1740^{* * *}$ & $-0.1263^{* * *}$ \\
\hline HGOLCF & $0.0390^{* * *}$ & 0.0126 & 0.0150 \\
\hline LGOHCF & $-0.1677^{* * *}$ & 0.0116 & 0.0003 \\
\hline $\mathrm{R}^{2}$ & 0.0499 & 0.0746 & 0.0582 \\
\hline$R_{\text {Adj }}^{2}$ & 0.0498 & -0.0577 & 0.0582 \\
\hline $\mathrm{F}$ & $519.84^{* * *}$ & $698.31^{* * *}$ & $612.46^{* * *}$ \\
\hline $\operatorname{LM}\left(\chi^{2}\right)$ & & $64,717^{* * *}$ & \\
\hline Hausman $\left(\chi^{2}\right)$ & & $502.61^{* * *}$ & \\
\hline \multirow[t]{2}{*}{ N. obs. } & 39,616 & 39,616 & 39,616 \\
\hline & \multicolumn{3}{|c|}{ Dependent variable: $D_{i t \text { ln }}$} \\
\hline$\alpha$ & $1.5621^{* * *}$ & $3.2274^{* *}$ & $2.7868^{* * *}$ \\
\hline CF (3) & $-2.8087^{* * *}$ & $-1.4984^{* * *}$ & $-1.5499 * * *$ \\
\hline AGE (1) & $-0.3847^{* * *}$ & $-0.9708^{* * *}$ & $-0.8213^{* * *}$ \\
\hline HGOLCF & $0.2765^{* * *}$ & 0.0968 & 0.1044 \\
\hline LGOHCF & $-0.6279 * * *$ & $0.3452^{* * *}$ & $0.3162^{* * *}$ \\
\hline $\mathrm{R}^{2}$ & 0.0810 & 0.1650 & 0.1404 \\
\hline$R_{\text {Ad j }}^{2}$ & 0.0809 & 0.0457 & 0.1403 \\
\hline $\mathrm{F}$ & $873.1^{* * *}$ & $1,712.67^{* * *}$ & $1,617.65^{* * *}$ \\
\hline $\operatorname{LM}\left(\chi^{2}\right)$ & & $92,564^{* * *}$ & \\
\hline Hausman $\left(\chi^{2}\right)$ & & $947.23^{* * *}$ & \\
\hline N. obs. & 39,616 & 39,616 & 39,616 \\
\hline
\end{tabular}

Notes: The variables are described in tables 1, 2 and 3. F test has as $H_{0}$ the statistical insignificance of the set of independent variables; the Breusch-Pagan Lagrange multiplier (LM) test follows a $\chi^{2}$ distribution and has as $H_{0}$ the non-relevance of the individual (unobservable) effects; Hausman test follows a $\chi^{2}$ distribution and has as $H_{0}$ that the individual (unobservable) effects are not correlated with the explanatory variables; the fixed effects models and the random effects models were computed using the White estimator.

OLS = ordinary least squares

* $=p$-value $<0.1 ; * *=p$-value $<0.05 ; * * *=p$-value $<0.01$.

Source: Elaborated by the authors. 
The results of the LM test are statistically significant at $1 \%$ for the three debt proxies, suggesting the rejection of $\mathrm{H}_{0}$, and thus, the individual effects are relevant in explaining the model, therefore an OLS regression is not the most efficient way of proceeding to the estimation. Consequently, the Hausman test should be used to see if the correlation between individual effects and explanatory variables is significant. The results of this test are significant at $1 \%$, suggesting the rejection of $\mathrm{H}_{0}$, and so the fixed effects model constitutes the most consistent and efficient estimation model.

In general, the reduced values of the determination coefficients, $R^{2}$ and $R^{2}{ }_{A d}$ j justify the poor explanatory quality of the models, with $D_{i t l n}$ being the one that presents the best fit to the data. However, the Fisher-Snedecor F test results are relevant at $1 \%$, suggesting that the independent variables are globally important regardless of the proxy used for the debt.

The empirical results support a significant negative relationship between the CF and the indebtedness in all models. This suggests that the presence of information asymmetry between the company and the credit market, on the one hand, and, on the other hand, the reluctance to open capital to external family members, should lead Portuguese family businesses to resort, first, to internally generated resources to support financing needs. This evidence is consistent with what is predicted by the POT and confirms expected relationship sign.

The variable AGE also has a significant negative relationship with the three models of indebtedness, suggesting that the capacity to accumulate profit increases with the life cycle of Portuguese family companies, reducing the need to resort to external funds. This evidence is consistent with the predicted by the POT and confirms expected relationship sign.

The evidence for CF and AGE converge with the studies of Acedo-Ramírez et al. (2017), Bjuggren et al. (2012), Croci et al. (2011), López-Gracia and SánchezAndújar (2007), Mehboob et al. (2015), Serrasqueiro et al. (2012, 2016), and Vieira (2014). The positive but not relevant relationship between the HGOLCF and debt proxies does not allow us to accept $\mathrm{H}_{2 \mathrm{a}-1}$. Finally, the insignificant positive relationship of the LGOHCF with the dependent variables $D_{i t}$ and $D_{i t s t}$ and the significant positive relationship with the dependent variable $D_{i t l n}$ contradict the assumptions of the POT and suggest the rejection of the $\mathrm{H}_{2 \mathrm{a}-2}$.

Table 10 summarizes the results of the test to the POT, through the impact of the FD in the variation of the indebtedness and the relationship between the determinants of the financing and the debt.

\section{Table 10}

Verification of the pecking order theory's investigation hypotheses

\begin{tabular}{|c|c|c|c|}
\hline Independent variables & $\begin{array}{l}\text { Expected } \\
\text { relationship }\end{array}$ & Estimated relationship & $\begin{array}{l}\text { Validation of } \\
\text { hypotheses }\end{array}$ \\
\hline$\alpha$ and $b_{P O}$ & $\alpha=0$ and $b_{\mathrm{PO}}=1$ & $\alpha \cong 0$ and $\mathrm{b}_{\mathrm{PO}} \cong 0$ & $\mathrm{H}_{2}:$ Not validated \\
\hline CF & - & - & $\mathrm{H}_{2 \mathrm{a}}:$ Validated \\
\hline AGE & - & - & $\mathrm{H}_{2 \mathrm{~b}}$ : Validated \\
\hline HGOLCF & + & n.s. & $\mathrm{H}_{2 \mathrm{c}-1}:$ Not validated \\
\hline LGOHCF & - & n.s./+ & $\mathrm{H}_{2 \mathrm{c}-2}:$ Not validated \\
\hline
\end{tabular}

Notes: The variables are described in tables 1, 2 and 3.

n.s. = non-significant .

Source: Elaborated by the authors.

\subsection{Conjoint Test}

Once the tests have been performed on each theory, Table 11 presents the results of the joint test of the Shyam-Sunder and Myers (1999) model and the partial adjustment model, taking into account the determinants of funding provided by the TOT and the POT. The behavior of the coefficient of adjustment $\lambda$ of the TOT model is compared with the coefficient $b_{P O}$ of the POT model, in order to identify which of the theories shows the best performance.

As previously mentioned, the model expressed in equation 11 includes the lagged variable $D_{i t-1}$, so the estimation of the model of the joint test uses the GMM system estimator of Blundell and Bond (1998). 
Table 11

Conjoint test

\begin{tabular}{|c|c|c|c|}
\hline \multirow{2}{*}{ Independent variables } & \multicolumn{3}{|c|}{ Dependent variables } \\
\hline & $D_{i t}$ & $D_{\text {it st }}$ & $D_{i t \ln }$ \\
\hline$D_{i t-1}$ & $0.5328^{* * *}$ & & \\
\hline $\mathrm{D}_{\mathrm{it}-1 \mathrm{st}}$ & & $0.4987^{* * *}$ & \\
\hline$D_{i t-1 \text { ln }}$ & & & $0.8248^{* * *}$ \\
\hline$\lambda$ & $0.4672 * * *$ & $0.5013^{* * *}$ & $0.1752^{* * *}$ \\
\hline FD & $0.0001^{* *}$ & $-0.0130^{* *}$ & -0.0172 \\
\hline ETR & -0.0001 & -0.00004 & -0.0007 \\
\hline NDTS (1) & $0.2328^{* * *}$ & $0.2451^{* * *}$ & 0.4901 \\
\hline GO (1) & $0.0910^{* * *}$ & & $0.74^{* * *}$ \\
\hline GO (2) & & $-0.1182^{* * *}$ & \\
\hline PROF (2) & $-0.5546^{* * *}$ & $-0.3493 * * *$ & $-2.0405^{* * *}$ \\
\hline SIZE (1) & $0.0369^{* * *}$ & $0.0334^{* * *}$ & $0.0273^{* * *}$ \\
\hline $\operatorname{AGE}(1)$ & $-0.0154^{* * *}$ & $-0.0121^{* * *}$ & $-0.0503^{* * *}$ \\
\hline TANG (1) & & $-0.0649 * * *$ & \\
\hline TANG (2) & $0.0574^{* * *}$ & & -0.0087 \\
\hline CF (3) & -0.0455 & -0.0168 & -0.3981 \\
\hline HGOLCF & 0.0449 & $0.0993^{* * *}$ & -0.0745 \\
\hline LGOHCF & $-0.1431 * * *$ & $-0.0438^{*}$ & $-0.3128^{* * *}$ \\
\hline Hansen & $1,121.49^{* * *}$ & $713.41^{* * *}$ & $339.10^{* * *}$ \\
\hline $\mathrm{m}_{1}$ & $-10.75^{* * *}$ & $-15.17^{* * *}$ & $-11.28^{* * *}$ \\
\hline $\mathrm{m}_{2}$ & $10.17^{* * *}$ & $8.29^{* * *}$ & $6.95^{* * *}$ \\
\hline Wald $\left(\chi^{2}\right)$ & $193,010.20^{* * *}$ & $101,429.50^{* * *}$ & $24,376.30^{* * *}$ \\
\hline N. obs. & 39,616 & 39,616 & 39,616 \\
\hline
\end{tabular}

Notes: The variables are described in tables 1,2 and 3. Hansen test has as $H_{0}$ the validation of the restrictions imposed by the use of instruments; $m_{1}$ and $m_{2}$ represent the first and second order autocorrelation tests, respectively, having as $H_{0}$ the absence of autocorrelation; the Wald test follows a $\chi^{2}$ distribution and has as $H_{0}$ that the independent variables, globally, do not explain the dependent variable.

* $=p$-value $<0.1 ; * *=p$-value $<0.05 ; * * *=p$-value $<0.01$.

Source: Elaborated by the authors.

The results of the Hansen test and the autocorrelation test are statistically significant at $1 \%$, suggesting, in both cases, the rejection of $\mathrm{H}_{0}$. The presence of autocorrelation justifies the use of dynamic panel models, but given the invalidity of the instruments, it is concluded that the results of the GMM system estimator are not considered robust. However, the values of the Wald test are relevant at $1 \%$, proposing the rejection of $\mathrm{H}_{0}$, and thus, the independent variables - taken globally - are significant to explain the dependent variables.

The empirical results show that the coefficients $\lambda$ decreased slightly with the independent variables of the POT model (tables 6 and 11) to determine the proxies of the indebtedness. As in the TOT model, positive $\lambda$ coefficients suggest that Portuguese family companies adjust the actual debt ratio to the optimal target. However, these estimates below 1 indicate that businesses face transaction costs that prevent them from reaching the optimal debt level completely. In addition, the coefficients $b_{P O}$ close to 0 , as occurred in the POT model, indicate that the financial deficit has no influence on the recourse to indebtedness.

It can be seen that the coefficient of adjustment $\lambda$ is much higher than the regression coefficient $b_{P O}$ of the variable FD in the three proxies of indebtedness. Moreover, both coefficients are statistically significant in the model of total debt $\left(\lambda=0.4672\right.$ and $\left.b_{P O}=0.0001\right)$ and in the model of short-term debt $(\lambda=0.5013$ and $\left.b_{P O}=-0.0130\right)$. This indicates that the TOT appears to have a better performance than the POT. However, apart from the proxy of indebtedness, it is found that $\lambda \neq 0$ and $b_{P O} \neq 0$, justifying that both theories can explain financing decisions. This evidence is consistent with the conclusions of the individual tests. 
Regarding the financing determinants, the independent variable NDTS loses significance in the model $\mathrm{D}_{\mathrm{it} \ln }$. The CF variable has no explanatory relevance in any model, while the HGOLCF variable only has relevance in the $\mathrm{D}_{\text {it st }}$ model. Finally, the relevant negative relationship of the LGOHCF variable in the three models of indebtedness is highlighted, contradicting the previous evidence and converging with the assumptions of the POT.

Table 12 summarizes the empirical results of the joint test.

Table 12

Verification of the hypotheses of investigation of the joint test

\begin{tabular}{lccc}
\hline Independent variables & Expected relationship & Estimated relationship & Validation of hypotheses \\
\hline$\lambda$ and $b_{\mathrm{PO}}$ & $\mathrm{b}_{\mathrm{PO}} \neq 0$ and $\lambda \neq 0$ & $\mathrm{~b}_{\mathrm{PO}} \neq 0$ and $\lambda \neq 0$ & $\mathrm{H}_{3}:$ Validated \\
\hline$\lambda$ and $\mathrm{b}_{\mathrm{PO}}$ & $\lambda>\mathrm{b}_{\mathrm{PO}}$ & $\lambda>\mathrm{b}_{\mathrm{PO}}$ & $\mathrm{H}_{4}:$ Validated \\
\hline$\lambda$ and $\mathrm{b}_{\mathrm{PO}}$ & $\mathrm{b}_{\mathrm{PO}}>\lambda$ & $\lambda>\mathrm{b}_{\mathrm{PO}}$ & $\mathrm{H}_{5}:$ Not validated \\
\hline
\end{tabular}

Notes: The variables are described in tables 1, 2 and 3.

n.s. = non-significant .

Source: Elaborated by the authors.

The results corroborate the previous conclusions, indicating that the financing decisions of Portuguese family companies are closer to the assumptions of the TOT than to the assumptions of the POT. In fact, the level of debt adjustment towards the optimal target is considerably higher than the magnitude of the impact of the deficit of funds on changes in indebtedness. This suggests acceptance of $\mathrm{H}_{4}$ and rejection of $\mathrm{H}_{5}$. The evidence described converges with the studies of Acedo-Ramírez et al. (2017), Ampenberger et al. (2013), Croci et al. (2011), Keasey et al. (2015), López-Gracia and Sánchez-Andújar (2007), and Serrasqueiro et al. $(2012,2016)$.

Although the variations in indebtedness are relatively scarcely influenced by insufficient internal financing, the results support that the TOT and the POT are not mutually exclusive; therefore, both can explain part of the financing decisions of these companies, suggesting the acceptance of $\mathrm{H}_{3}$.

\section{CONCLUSION}

The results of the isolated test to the TOT suggests that the Portuguese family companies adjust the level of indebtedness towards the target, although influenced by transaction and adjustment costs that keep them away from the optimum.

The results of the isolated test to the POT, considering the model of Shyam-Sunder and Myers (1999), suggest that, when the financing needs are not covered by the internal resources, the Portuguese family companies resort to sources other than debt.

Confronting the two tests, we conclude that the magnitude of the impact of the financial deficit is greater in total debt ratio and smaller in short-term debt ratio and in debt-to-equity ratio, although the velocity of adjustment to the optimal ratio is higher in short-term debt. In addition, the negative mean value of financial deficit means that those companies generate internal surpluses that compensate for the financing needs.
The results of the joint test corroborate the previous conclusions, justifying the better performance of the TOT in explaining the financing decisions of Portuguese family companies. In addition, the significant positive relationship with SIZE is consistent with the TOT.

On the other hand, the results of the isolated test to the POT, considering the determinants of the financing, show significant negative relationships with CF and AGE.

It is anticipated that the greater convergence of interests, given family/business interaction, and the consequent decrease in agency costs will result in higher levels of recognized reputation and thus easier access to indebtedness. In this context, Portuguese family companies adjust the level of debt, offsetting the costs associated with tax benefits, through decisions on capital structure closer to the TOT, but not exclusively, because a positive, albeit reduced, change in total debt resulting from financial deficit was identified. 


\section{REFERENCES}

Acedo-Ramirez, M., Ayala-Calvo, J., \& Navarrete-Martinez, E. (2017). Determinants of capital structure: Family businesses vs non-family firms. Czech Journal of Economics and Finance, 67(2), 80-103.

Adair, P., \& Adaskou, M. (2015). Trade-off-theory vs pecking order theory and the determinants of corporate leverage: Evidence from a panel data analysis upon French SMEs (2002-2010). Cogent Economics \& Finance, 3(1), 1006477.

Almeida, H., \& Campelo, M. (2010). Financing frictions and the substitution between internal and external funds. Journal of Financial and Quantitative Analysis, 45(3), 589-622. https:// doi.org/10.1017/S0022109010000177

Ampenberger, M., Schmid, T., Achleitner, A., \& Kaserer, C. (2013). Capital structure decisions in family firms: Empirical evidence from a bank-based economy. Review of Managerial Science, 7(3), 247-275.

Arellano, M., \& Bond, S. (1991). Some tests of specification for panel data: Monte Carlo evidence and an application to employment equations. The Review of Economic Studies, 58(2), 277-297.

Baltagi, B. (2005). Econometric analysis of panel data (3rd ed.). John Wiley \& Sons.

Ban, M., \& Chen, C-C. (2019). Ambiguity and capital structure adjustments. International Review of Economics \& Finance, 64, 242-270. https://doi.org/10.1016/j.iref.2019.05.009

Bauweraerts, J., \& Colot, O. (2012). Pecking-order or static trade-off theory in family firms? Evidence from Belgium. International Business Research, 5(11), 1-11.

Bjuggren, P., Duggal, R., \& Giang, D. (2012). Ownership dispersion and capital structures in family firms: A study of closed medium-sized enterprises. Journal of Small Business \& Entrepreneurship, 25(2), 185-200.

Blanco-Mazagatos, V., Quevedo-Puente, E., \& Castrillo, L. A. (2007). The trade-off between financial resources and agency costs in the family business: An exploratory study. Family Business Review, 20(3), 199-213.

Blanco-Mazagatos, V., Quevedo-Puente, E., \& García, J. (2009). La estructura financiera de la empresa familiar y el cambio generacional. Spanish Journal of Finance and Accounting/ Revista Española de Financiación y Contabilidad, 38(141), 57-73.

Blundell, R., \& Bond, S. (1998). Initial conditions and moment restrictions in dynamic panel data models. Journal of Econometrics, 87(1), 115-143.

Caetano, A. (2011). Decisões da estrutura de capitais das PME da Beira Interior: Teoria do trade-off vs teoria da pecking order [Master Thesis]. Universidade da Beira Interior.

Chami, R. (2001). What is different about family businesses? [Working Paper]. International Monetary Fund.

Chernenko, D. (2019). Capital structure and oligarch ownership. Economic Change and Restructuring, 52, 383-411. https://doi. org/10.1007/s10644-018-9226-9
Correia, T. (2003). Determinantes da estrutura de capital das empresas familiares portuguesas [Master Thesis]. Universidade do Algarve.

Croci, E., Doukas, J., \& Gonenc, H. (2011). Family control and financing decisions. European Financial Management, 17(5), 860-897.

Csákné F., \& Karmazin, G. (2016). Financial characteristics of family businesses and financial aspects of succession. Budapest Management Review, 47(11), 46-58.

Dang, V. (2005). Testing the trade-off and pecking order theories: Some UK evidence [Working Paper]. Leeds University Business School.

Decree-Law n. 98. (2015, June 2). Transpõe a Diretiva n. ${ }^{\circ}$ 2013/34/ UE, do Parlamento Europeu e do Conselho, de 26 de junho de 2013, relativa às demonstrações financeiras anuais, às demonstrações financeiras consolidadas e aos relatórios conexos de certas formas de empresas. https://dre.pt/home/-/ dre/67356342/details/maximized

Ellul, A. (2008). Control motivations and capital structure decision [Working Paper]. Indiana University.

European Commission. (2009). Overview of family-businessrelevant issues: Research, networks, policy measures and existing studies.

Fama, E., \& French, K. (2002). Testing trade-off and pecking order predictions about dividends and debt. The Review of Financial Studies Spring, 15(1), 1-33.

Fazzari, S., Hubbard, G., \& Petersen, B. (1988). Financing constraints and corporative investments. Brookings Papers on Economic Activity, 1, 141-206.

Frank, M., \& Goyal, V. (2008). Trade-off and pecking order theories of debt. Handbook of Empirical Corporate Finance, 2, 135-202.

Frank, M., \& Goyal, V. (2009). Capital structure decisions: Which factors are reliably important? Financial Management, 38(1), 1-37.

Gallo, M., Tàpies, J., \& Cappuyns, K. (2004). Comparison of family and nonfamily business: Financial logic and personal preferences. Family Business Review, 17(4), 303-318.

Gottardo, P., \& Moisello, A. (2014). The capital structure choices of family firms: Evidence from Italian medium-large unlisted firms. Managerial Finance, 40(3), 254-275.

Hillen, C., \& Lavarda, C. E. F. (2020). Orçamento e ciclo de vida em empresas familiares em processo de sucessão. Revista Contabilidade \& Finanças, 31(83), 212-227. https://doi. org/10.1590/1808-057x201909600

Jensen, M., \& Meckling, W. (1976). Theory of the firm: Managerial behavior, agency costs and ownership structure. Journal of Financial Economics, 3(4), 305-360.

Keasey, K., Martinez, B., \& Pindado, J. (2015). Young family firms: Financing decisions and the willingness to dilute control. Journal of Corporate Finance, 34(C), 47-63. 
King, M., \& Santor, E. (2008). Family values: Ownership structure, performance and capital structure of Canadian firms. Journal of Banking \& Finance, 32(11), 2423-2432.

Kraus, A., \& Litzenberger, R. (1973). A state-preference model of optimal financial leverage. The Journal of Finance, 28(4), 911-922.

Liu, S., Qi, H., \& Xie, Y. A. (2020). Executive compensation and capital structure. Applied Economics, 52(8), 825-838. https:// doi.org/10.1080/00036846.2019.1659927

López-Gracia, J., \& Sánchez-Andújar, S. (2007). Financial structure of the family business: Evidence from a group of small Spanish firms. Family Business Review, 20(4), 269287.

López-Gracia, J., \& Sogorb-Mira, F. (2008). Testing trade-off and pecking order theories financing SMEs. Small Business Economics, 31(2), 117-136.

Martinez, L. B., Vigier, H. P., Briozzo, A. E., \& Guercio, M. B. (2021). La estructura financiera de las empresas de base tecnológica. Revista Contabilidade \& Finanças, 31(84), 444457. https://doi.org/10.1590/1808-057x201909580

Mehboob, F., Tahir, S., \& Hussain, T. (2015). Impact of family ownership on financial decisions of a firm: An analysis of pharmaceutical and chemical sectors in Pakistan. EuroAsian Journal of Economics and Finance, 3(2), 103-112.

Mishra, C., \& McConaughy, D. (1999). Founding family control and capital structure: The risk of loss of control and the aversion to debt. Entrepreneurship Theory and Practice, 23(4), 53-53.

Mohamadi, A. (2012). Choice of financing in family firms [Master Thesis]. Jönköping International Business School.

Murteira, J., Castro, V., \& Martins, R. (2016). Introdução à econometria. Almedina.

Myers, S. (1984). The capital structure puzzle. The Journal of Finance, 39(3), 574-592.

Myers, S., \& Majluf, N. (1984). Corporate financing and investment decisions when firms have information that investors do not have. Journal of Financial Economics, 13(2), 187-221.

Ramalho, J., \& Silva, J. (2009). A two-part fractional regression model for the capital structure decision of micro, small, medium and large firms [Working Paper]. Universidade de Évora.

Rita, R. (2011). Impacto da propriedade familiar do capital no processo de decisão de financiamento das empresas portuguesas [Doctoral Thesis]. Universidade de Évora.

Romano, C., Tanewski, G., \& Smyrnios, K. X. (2001). Capital structure decision making: A model for family business. Journal of Business Venturing, 16(3), 285-310.

Schulze, W., Lubatkin, M., \& Dino, R. N. (2003a). Exploring the agency consequences of ownership dispersion among the directors of private family firms. The Academy of Management Journal, 46(2), 179-194.

Schulze, W., Lubatkin, M., \& Dino, R. N. (2003b). Toward a theory of agency and altruism in family firms. Journal of Business Venturing, 18(4), 473-490.
Serrasqueiro, Z., \& Caetano, A. (2015). Trade-off theory vs pecking order theory: Capital structure decisions in a peripheral region of Portugal. Journal of Business Economics and Management, 16(2), 445-466.

Serrasqueiro, Z., \& Nunes, P. (2010). Are trade-off and pecking order theories mutually exclusive in explaining capital structure decisions? African Journal of Business Management, 4(11), 2216-2230.

Serrasqueiro, Z., Armada, M., \& Nunes, P. (2011). Pecking order theory vs trade-off theory: Are service SMEs' capital structure decisions different? Service Business, 5(4), 381-409.

Serrasqueiro, Z., Nunes, P., \& Silva, J. (2012). Are financing decisions of family-owned SMEs different? Empirical evidence using panel data. Journal of Management \& Organization, 18(3), 363-382.

Serrasqueiro, Z., Nunes, P., \& Silva, J. (2016). The influence of age and size on family-owned firms' financing decisions: Empirical evidence using panel data. Long Range Planning, 49(6), 723-745.

Setia-Atmaja, L., Tanewski, G., \& Skully, M. (2009). The role of dividends, debt and board structure in the governance of family controlled firms. Journal of Business Finance \& Accounting, 36(7-8), 863-898.

Shyam-Sunder, L., \& Myers, S. (1999). Testing static tradeoff against pecking order models of capital structure. Journal of Financial Economics, 51(2), 219-244.

Silva, S. (2012). Estrutura de capitais: Teste às teorias do trade-off vs pecking order [Master Thesis]. Universidade do Minho.

Sogorb-Mira, F., \& López-Gracia, J. (2003). Pecking order vs tradeoff: An empirical approach to the small and medium enterprise capital structure [Working Paper]. Instituto Valenciano de Investigaciones Económicas.

Steier, L., Chrisman, J., \& Chua, J. (2004). Entrepreneurial management and governance in family firms: An introduction. Entrepreneurship Theory and Practice, 28(4), 295-303.

Tahir, S., Sabir, H., \& Shah, S. (2016). Impact of family ownership on financing decisions: A comparative analysis of companies listed at the KSE. Pakistan Business Review, 17(4), 985-1005.

Thanh, L. T., \& Huong, D. M. (2017). Determinants of capital structure: An empirical study on Vietnamese listed firms. Serbian Journal of Management, 12(1), 77-92.

Tong, G., \& Green, C. (2005). Pecking order or trade-off hypothesis? Evidence on the capital structure of Chinese companies. Applied Economics, 37(19), 2179-2189.

Vieira, E. (2014). Capital structure determinants in the context of listed family firms. Journal of Economy, Business and Financing, 2(1), 12-25.

White, H. (1980). A heteroskedasticity-consistent covariance matrix estimator and a direct test for heteroskedasticity. Econometrica, 48(4), 817-838.

Woodman, J. (2017). Agency theory, behavioral agency model \& stewardship theory and their relationship with succession in family firms: A literature review [Working Paper]. ResearchGate. 